Working Paper 86-6

\title{
A CRITIQUE OF THEORIES OF MONEY STOCK DETERMINATION
}

Robert L. Hetzel

Federal Reserve Bank of Richmond

October 1986

We are grateful to Marvin Goodfriend and Bob King for a number of valuable suggestions as well as to Monica Hargraves and Tony Kuprianov for helpful comments. The views expressed in this paper are solely those of the authors and do not necessarily represent those of the Federal Reserve Bank of Richmond or the Federal Reserve System. 


\section{Introduction}

Many different models of money stock determination exist in the literature. An attempt is made here to understand why the differences in these models arise. Differences in models are ascribed first to the (usually implicit) role assigned to the price level. From this perspective, models fall into two categories. Models in the quantity theory tradition require that the price level adjust in order to cause the real quantity of money to equal the real quantity demanded. In contrast, in the real bills or banking school tradition, the nominal quantity of money adjusts in order to provide the real quantity demanded. Much of the discussion below deals with the way in which the macroeconomics inspired by Keynes' General Theory encouraged models in the latter tradition. Differences in models also arlse according to whether the monetary authority directly manipulates an interest rate or a reserve aggregate. Sec. 2 presents a model of the money stock general enough to include the models discussed in succeeding sections as special cases. Variation in its parameter expressing the extent to which the monetary authority smooths the rate of interest allows it to capture the range of operating procedures running from total reserves control to rate pegging.

\section{A general model of the money stock}

The model In this section is McCallum's (1986) model extended to include the banking sector. Let $r_{t}$ denote the nominal rate of interest; $p_{t}, h_{t}$, and $m_{t}$ denote logs of the price level, reserves, and the nominal money stock, respectively. Let $t$ denote time. Also, $v_{t}, n_{t}$, and $e_{t}$ are independent white noise disturbances. $E$ is the expectations operator and $I_{t-1}$ is the information set of realizations of variables dated $t-1$ or earlier. Equation (1) is a reduced form derived by eliminating real output through equating an aggregate demand and aggregate supply schedule. The latter makes deviations in real output from a normal value a function of unanticipated realizations of the price level. The assumption of rational expectations then endows the model with a natural rate of 
interest in that the real rate of interest is unaffected by the systematic actions of monetary policy.

Equation (1) expresses the nominal interest rate as the sum of expected inflation (first term) plus the real rate of interest (last three terms), where the real rate of interest equates the flow of investment and saving. Equation (2) is a money demand function. In (3), the monetary rule is specified in terms of control of a reserves aggregate (high-powered money, total bank reserves, or nonborrowed reserves). Equation (4) defines the relationship between nominal money, the interest rate, and reserves. Also, $m_{t}^{d}=m_{t}^{5}$. The model comprises five endogenous variables $\left(r_{t}, m_{t}, p_{t}, h_{t}\right.$, and $\left.E_{p_{t+1}}\right)$ and can be solved with the constraint imposed by rational expectations.

$$
\begin{array}{lc}
r_{t}=\left[E\left(p_{t+1}: I_{t-1}, r_{t}\right)-p_{t}\right]+b_{0}+b_{1}\left[p_{t}-E\left(p_{t}: I_{t-1}\right)\right]+v_{t} & b_{1}<0 \\
m_{t}^{d}-p_{t}=c_{0}+c_{1} r_{t}+c_{2}\left[p_{t}-E\left(p_{t}: I_{t-1}\right)\right]+n_{t} & c_{1}<0<c_{2} \\
h_{t}=u_{0}+u_{1} t+\lambda\left(r_{t}-\bar{r}\right) & 0<\lambda \\
m_{t}^{s}=d_{0}+d_{1} r_{t}+d_{2} h_{t}+e_{t} & d_{1}<0<d_{2}
\end{array}
$$

The parameter $\lambda$ measures the degree to which the monetary authority smooths the nominal interest rate. As $\lambda$ becomes large, the interest rate is pegged at $\vec{r}$. The rule incorporated in (3) provides for a complete future offset of the contemporaneous innovation in reserves that arises because of rate smoothing. Money fluctuates randomly around a trend line. Alternatively, (5) provides for no offset to innovations in reserves; money becomes a random walk.

$$
h_{t}=h_{t-1}+u_{1}+\lambda\left(r_{t}-\bar{r}\right) \quad 0<\lambda
$$

In a model incorporating the natural-rate hypothesis, an arbitrary interest rate target renders nominal money and the price level indeterminate [Sargent (1979), Pp. 92-95; Sargent and Wallace (1975)]. Two kinds of interest rate targets are compatible with nominal money and price level determinacy. First, indeterminacy does not obtain if the interest rate is used by the monetary authority as an instrumental variable for controlling a nominal variable [Parkin 
(1978); McCallum (1981)]. Second, Indeterminacy does not obtain in the case of an interest rate peg provided two requirements are fulfilled. 2 / The trend rate of inflation chosen by the monetary authority, which above is the trend rate of growth of money $\left(u_{1}\right)$, must equal the difference between the nominal rate target $(\bar{r})$ and the expected real rate $\left(b_{0}\right)$ [Canzoneri, Henderson, and Rogoff (1983), appendix]. Also, the monetary rule must define the extent to which the contemporaneous Innovation in money due to rate smoothing will be offset subsequently [Dotsey and King (1983), appendix, and McCallum (1986)].

In order to illustrate how the model works in a regime of rate pegging, consider a transitory rightward shift in the public's investment schedule captured by a positive realization of $v_{t}$. An incipient rise in the market rate of interest causes the monetary authority to increase reserves. Nominal money, $m_{t}$, and the price level, $p_{t}$, rise. Two separate effects keep the market rate approximately equal to $\bar{r}$. First, given (3), the public does not anticipate a corresponding rise in $\mathrm{m}_{t+1}$ and $\mathrm{p}_{t+1}$. Consequently, the expected rate of inflation from to $t+1$ falls below trend. A reduction in the inflation premium built into the nominal rate mitigates a rise in $r_{t}$. Second, the price level surprise associated with a higher than anticipated value of $p_{t}$ stimulates output, and the public's savings schedule shifts rightward. The combination of these effects keeps the nominal rate of interest at the targeted value.

In this natural-rate model, the price of nominal money is the inverse of the price level. (The interest rate is the price of real, not nominal, money.) The supply and demand schedules for nominal money are graphed with the inverse of the price level on the vertical axis and nominal money on the horizontal axis. The demand schedule for nominal money balances derives from the real money demand function (2) evaluated at different price levels. An increase in the price level (a fall in the price of nominal money) in itself leads to a proportional rise in the demand for nominal money. Given the particular money 
supply rule (3), which ties down $p_{t+1}$ independently of $p_{t}$, a rise in $p_{t}$ leads the public to anticipate a reduction in the one-period inflation rate. This reduction increases the demand for nominal money. Finally, a rise in $p_{t}$ given $E\left(p_{t}: I_{t-1}\right)$, leads to an increase in the demand for nominal money through an increase in real output. For all these reasons, the demand for nominal money is inversely related to the price level. The money supply rule (3) produces a vertical supply of nominal money schedule, which shifts over time at a rate determined by the parameter $u_{1}$.

Assume a rate peg of $\overline{\mathbf{r}}$ and consider first the effect of a positive monetary shock $\left(n_{t}>0\right)$. Both the nominal money demand and supply schedules shift rightward. The supply schedule shifts because the monetary authority increases the money stock in order to prevent a rise in $r_{t}$ above $\bar{r}$. Consider next the effect of a positive real shock $\left(v_{t}>0\right)$. The nominal money demand schedule is unaffected. The supply schedule shifts rightward, however, because of the monetary authority's defense of its rate peg. The price level rises.

The monetary rule determines the characteristics of the supply and demand schedules for nominal money. A well-defined rule is, therefore, a necessary condition for the existence of a determinate price level. This rule determines the nature of the nominal money supply schedule by setting the trend rate of growth of money, the degree of interest rate smoothing, and the extent to which contemporaneous innovations in money are offset. It also determines the nature of the nominal money demand schedule by rendering the real demand for money well defined. The rule allows the public to form an expectation of the future money stock, which allows formation of an expectation of the future price level. The contemporaneous demand for real money then is well defined.

A major source of confusion has been the frequent failure to recognize that the reserves-money multiplier relationship (4) does not summarize behavioral relationships important to the determination of the money stock in a regime of 
rate control. Furthermore, in those instances when the conditions for the superfluity of the multiplier relationship have been recognized, it has usually been concluded that "money is demand determined." Consider a regime of a rate peg. Given knowledge of the parameters of (3) and (4), it is possible to form an expectation of $p_{t+1} \cdot \underline{3} /$ With $r_{t}$ equal $\bar{r}$, it is then possible to solve (1) and (2) for $m_{t}$ and $p_{t}$. Given the solution for $m_{t}, h_{t}$ can be derived from (4). It is possible with a rate peg, however, to solve for $m_{t}$ without also solving for $h_{t}$, the contemporaneous value of the reserve aggregate.

The failure of the reserves-money multiplier relationship to summarize behavioral relationships important in the determination of the money stock in a regime with a rate peg extends to a regime in which the interest rate is used as an instrumental variable for controlling macroeconomic variables [McCallum (1981), p. 322; Goodfriend (1982), p. 8]. For example, assume that the monetary authority consistently sets the interest rate to achieve an expected value for money, $\bar{m}$. The rate target, $r^{*}$, can be solved for by using (2) to form an expectation of money and by substituting $\bar{m}$ for this expectation.

$$
r^{*}=1 / c_{1}\left[\overline{\mathbf{m}}-c_{0}-E\left(p_{t}: I_{t-1}\right)\right]
$$

Equations (1) and (2) and knowledge of $\bar{m}$ allow the public to determine the expected value of $p_{t+1}$. With $r_{t}=r^{*}$, the relevant system of equations is now fust equations (1) and (2), which can be solved for $m_{t}$ and $p_{t}$. The reservesmoney multiplier (4) is superfluous to determination of the money stock.

This result can be seen by examining a simple reserves-deposits multiplier:

$$
D=(D / R) * \cdot R \text {, }
$$

where $D$ is deposits, $(D / R)$ * is banks' equilibrium deposits-reserves ratio, and $R$ is total reserves of banks. In order for (8) to be a useful summary of deposit determination, $R$ must be determined independently from $D$; also $D$ must adjust to $(D / R) *$, given $R$. Neither of these two conditions is fulfilled in a regime of rate control. First, the targeted rate determines the cost to the banking 
system of credit extension; therefore, deposit creation is determined by shifts in the nominal credit demand schedule of the nonbank public. These shifts are determined by the shocks that originate in the real and monetary sectors of the economy and by the choice of the monetary rule. Deposits and reserve demand are determined simultaneously with credit creation. As a consequence of defending its rate target, the monetary authority, by creating an infinitely elastic supply of reserves, accommodates whatever reserve demand emerges. 4 /

Second, as a consequence of maintaining its rate target, the monetary authority necessarily supplies reserves to preclude any effect on deposits of changes in banks' equilibrium ratio of reserves to deposits. For example, consider an increase in this ratio due to a rise in equilibrium excess reserves or due to a shift of deposits from banks with a low required reserve ratio on marginal deposits to banks with a high ratio. In both cases, the monetary authority must supply additional reserves in order to prevent the funds rate from rising. $5 /$ In a regime of rate targeting, neither the quantity of reserves nor the desired reserves-deposits ratio of the banking system exercises a causal role in the determination of the money stock.

When economists have noted the irrelevance of the reserves-money multiplier in a regime of rate control, they have usually concluded that money is demand determined [for example, Plerce and Thomson (1972)]. This conclusion is misleading in a natural-rate model. The importance to money-stock determination of factors affecting the supply of money is obvious in the case of real sector shocks and also appears in the role played by the monetary rule. The form of this rule shapes the time series behavior of nominal money independently of the nature of the demand function for real money.

\section{Thornton's model of the money stock}

Henry Thornton exposited the first rigorous model of a non-commodity money. Suspension by the Bank of England in 1797 of convertibility of its notes into 
gold led to the famous bullionist - anti-bullionist debate. The anti-bullionist Directors of the Bank argued that note creation by the Bank could continue to be regulated by the real bills principle. That is, money creation would be limited by. the public's demand. The bullionist Henry Thornton countered this view with a model of the money stock in the quantity theory tradition [Hetzel (1986)]. In order for nominal money to play a causal role in determining the price level, at least some of the determinants of nominal money supply must differ from the determinants of real money demand. Thornton achieved this differentiation through a model of the money stock that incorporated a natural rate of interest, that is, a real rate of interest determined ultimately only by nonmonetary phenomena. According to Thornton, the monetary authority creates money by driving a wedge between the market rate of interest, controlled by its discount rate, and the natural rate of interest, determined in the market for real capital. This wedge between the market and the natural rate does not affect the demand for real money, so the price level must adjust to the associated nominal money creation [Thornton (1802), pp. 227;253-4;255-6].

The natural rate model of Sec. 2 is similar in spirit to Thornton's model, where changes in nominal money derive from discrepancies between the market and natural rate of interest. Assume a rate peg of $\bar{r}$ and rewrite the reduced-form expression for the nominal rate of interest (1) as (9). The left side of (9) can be viewed as the difference between the market rate, $\bar{r}$, and the natural rate, $\left(b_{0}+v_{t}\right)$. Also, $p_{t}$ is a function of the current money stock.

$$
\begin{aligned}
& \bar{r}-\left(b_{0}+v_{t}\right)=\left[E\left(p_{t+1}: I_{t-1}, r_{t}\right)-p_{t}\right]+b_{1}\left[p_{t}-E\left(p_{t}: I_{t-1}\right)\right] \quad b_{1}<0 \\
& p_{t}=E\left[m_{t}, E\left(p_{t+1}: I_{t-1}\right), n_{t}, v_{t}, E\left(p_{t}: I_{t-1}\right)\right] \quad \partial p_{t} / \partial m_{t}>0
\end{aligned}
$$

Consider a positive real sector shock, $v_{t}>0$. The value of the left side of (9) falls. The sum of the two terms on the right side must fall; therefore, $p_{t}$ must rise. Because $p_{t}$ varies positively with $m_{t}, m_{t}$ must rise. Consequently, when shocks originate in the real sector, shifts in the supply of nominal money 
may be considered, in the spirit of Thornton's model, to be a function of the difference between the market and the natural rate. In contrast, the demand for real money is a function of just the market rate. Finally, in the spirit of Thornton's model, the model of Sec. 2 implies the absence of any permanent relation between the interest rate and nominal money.

\section{Pigou's reserves-money multiplier model}

As had happened in the Napoleonic War, suspension of the gold standard in World War I spurred theorizing about money stock determination. In 1917, A. C. Pigou (1917) introduced a reserves-money multiplier model. His model possesses relationships analogous to those of (2), (3), and (4) of the model of Sec. 2 . Pigou posits a real money demand function in the form of the Cambridge cashbalances version of the quantity equation. He discusses a variety of institutional arrangements for determining high-powered money. He formulates the money supply function as the product of high-powered money and a multiplier expressed in terms of the nonbank public's desired currency to money ratio and banks' desired reserves to deposits ratio. Finally, the nominal money supply function is equated to the product of the price level and the real money demand function. Pigou's model is in the spirit of the natural-rate model of Sec. 2, despite the absence of any formal way of incorporating the natural-rate hypothesis. In particular, the scale variable in the money demand function is understood as a nonmonetary phenomenon. Consequently, when the nominal quantity of money changes, the price level must do the work of bringing the public's real quantity of money back into equality with the real quantity demanded. 6 /

Reasoning within Pigou's static reserves-money multiplier framework, Patinkin (1961, p. 116) states that a necessary condition for rendering the price level "determinate is that there be an exogenous fixing of (1) some nominal quantity and (2) some rate of return." That is, the magnitude of some nominal quantity must be set and the real demand for this nominal quantity must 
be well defined. For example, fixing high-powered money, which possesses a nominal interest rate of zero, fixes the price level. Note that in the dynamic model of Sec. 2 a well-defined monetary rule replaces the requirement of "an exogenous fixing of some nominal quantity." (In Pigou's model, when it is assumed that nominal money is the nominal quantity fixed, it is appropriate to adopt the usual practice of referring to the money stock as the "money supply." In the dynamic model of Sec. 2, however, where the money stock is determined by factors affecting both demand and supply, this practice is inappropriate.)

\section{The Tinbergen model}

Models of the money stock inspired by the economics of the General Theory reflect Keynes' liquidity preference theory of interest. In the General Theory, Keynes omits an aggregate supply function with a natural rate of output in order to allow equilibrium levels of output below full employment. In this way, he also allows variations in output to equilibrate savings and investment. The role of the interest rate is to equilibrate the demand and supply of money through affecting the speculative demand for money. A fall, say, in the interest rate, relative to what investors consider a long-run normal rate, increases the speculative demand for money as investors, anticipating a future rise in rates and a capital loss on bonds, move out of bonds into money [Keynes (1936), Pp. 201-202]. Keynes' theory rejects the idea of a natural rate of interest. The implicit assumption that the price level is fixed or is determined as a nonmonetary phenomenon allows each nominal quantity of money to be associated with a different equilibrium real interest rate.

Tinbergen's (1939, 1951) model of the money stock incorporated Keynes' theory of liquidity preference and continues to be standard in the literature. [See Telgen (1964, 1970) for an exposition.] It serves as the core of the financial sector of large-scale econometric models [de Leeuw (1965), Goldfeld (1966), and Modigliani, Rasche, and Cooper (1970)]. Also, it is the primary 
model used by the Federal Reserve [Thomson, Pierce, and Parry (1975)] to forecast money. It is commonly used to study monetary control issues [Davis (1974), LeRoy (1979), Sivesind (1980), Tinsley (1982) and Lindsey (1984)].

The Tinbergen model possesses relationships analogous to those of (2), (3), and (4) of the model of Sec. 2. Tinbergen includes a standard real money demand function. He assumes that the monetary authority sets values for the discount rate and for nonborrowed reserves. The money supply function is bullt around the behavior of banks' demand for free reserves. Let FR be free reserves; NBR nonborrowed reserves; RR required reserves; ER excess reserves; $B R$ borrowed reserves; Ir the legal required reserve ratio; D deposits; $r$ the interest rate; and rd the central bank discount rate. NBR and rd are values set by the policymaker. (For expositional simplicity, currency is ignored).

$$
\begin{aligned}
& F R=N B R-R R=E R-B R \\
& R R=N B R-F R \\
& R R=r r \cdot D \\
& F R=f r(r: r d)
\end{aligned}
$$

Free reserves are defined in alternative ways in (11) and (11a), and (12) defines required reserves. Equation (13) explains bank demand for free reserves as a function of the rate of interest, given the discount rate. The money (deposit) supply function (15) is derived by substituting (12) and (13) into (11a) and solving for money (deposits).

In expostions of this model, no distinction is made between nominal and real money, and the price level never appears. The model is written as follows:

$$
\begin{aligned}
& D^{d}=c_{0}+c_{1} r+c_{2} Y \\
& D^{s}=1 / r r[\overline{N B R}-f r(r: r d)]
\end{aligned}
$$

(Y is real output.) The real money demand function (14) is equated to the nominal money supply function (15) in order to determine the interest rate, which is substituted into (14) or (15) in order to solve for (nominal and real) 
money. Because real money equals nominal money divided by the price level, in order to equate (14) and (15) and solve for D and $r$, it is necessary to take the price level as given. In a natural-rate model, the price level equilibrates the nominal quantities of money supplied and demanded. In the Tinbergen model, the rate of interest equilibrates the nominal quantity of money supplied and the nominal (and real) quantity of money demanded. In the latter model, the price level must be given in order to determine the nominal quantity of money. Causation runs from prices to money. Much of the popularity of the Tinbergen model has derived from the association of (14) and (15), respectively, with money demand and supply functions. The appeal of this application of the supply and demand apparatus to money stock determination, however, requires a willingness to assume that the price level is fixed.

The character of the Tinbergen model derives not so much from its assumptions about bank behavior, as from its assumption about the role assigned to the price level. When the Tinbergen model was first incorporated in the large-scale econometric models in the mid-1960s, these models possessed a Phillips curve in which inflation was inversely related to excess capacity or the unemployment rate. Although the price level was not fixed in the larger models, it was determined as a nonmonetary phenomenon. Consequently, the character of the Tinbergen model conveyed in its expositions remained the same when it was incorporated in the larger models, despite the fact that in the larger models the price level was no longer exogenous. If, however, the Tinbergen model were to be used in a larger model incorporating an expectations-adjusted Phillips' curve and the assumption of rational expectations, then its character would be transformed from that suggested by its expositions.

It is Instructive to compare the Pigovian and Tinbergen models. Both comprise a real money demand function and a reserves-money multiplier relationship and both assume reserve-aggregate control. Explicit incorporation of 
price-level determination in the Pigovian model and implicit exogeneity of the price level in the Tinbergen model, however, make these models very different. In the latter, but not the former, the determinants of the public's demand for real money balances are determinants of the nominal quantity of money. A major source of confusion in the money supply literature is the practice of modeling bank behavior only without also incorporating price level determination. This practice leaves the character of the resulting model ambiguous. I/

By omitting the reduced form (1) of the model of Sec. 2, the Tinbergen model makes innovations in nominal money identical to shocks to the real money demand function. Equate (14) and (15) and transpose the $1 / \mathrm{rr}$ term so that the left side becomes the reserve demand schedule and the right side becomes the reserve supply schedule.

$$
\left[c_{0}+c_{1} r+c_{2} Y\right] \operatorname{rr}=\overline{\mathrm{NBR}}-\mathrm{fr}(r: r d)
$$

Reserve demand, the left side of (16), is identified with the public's demand for real money balances. In any model, changes in reserve demand derive from changes in bank credit and the accounting link in a fractional reserves system between bank credit and deposits. As exposited, the Tinbergen model makes excess supply in the credit market identical to excess demand in the market for the quantity of money. The post-War preeminence of Keynesian liquidity preference theory made this assumption seem natural.

The money supply and demand schedules in the natural-rate model of Sec. 2 differ from those of the Tinbergen model. In the latter, they are graphed with (nominal and real) money on the horizontal axis and the interest rate on the vertical axis. The money demand schedule is a real money demand schedule. With nonborrowed reserves targeting, the money supply schedule is upward sloping because a higher interest rate produces a lower level of free reserves - excess reserves fall and borrowed reserves rise. This rise in reserves available to support deposits increases money supply. An increase, say, in nonborrowed 
reserves causes the money supply schedule to shift rightward. The interest rate falls and the money stock Increases as the public is moved along its real money demand schedule. In a regime of rate control, the money supply schedule is horizontal [Pierce and Thomson (1972), p. 119]. Kaminow (1977, p. 391), employing Tinbergen's model, states:

With an interest rate instrument, the rate is set so as to achieve a particular point on the demand for money curve - the point which is thought to coincide with the targeted stock. . . . the authorities hold the supply of money curve horizontal at the chosen rate in the hope that it will cross the demand curve at the targeted money stock. For this reason, misses are due only to variances in the demand for money.

The frequent fallure of economists to incorporate explicitly their assumptions about the role assigned to the price level has obscured the character of their models of the money stock. A similar criticism is made below about the failure of economists to incorporate explicitly the way in which the monetary regime affects the working of their models. Confusion has been especially great over the effect of the choice by the monetary authority between reserves and interest rate manipulation.

\section{Use of reserves-money multiplier models in a regime of rate control}

\section{Sources of confusion}

As discussed in Sec. 2, in a regime of rate control, the reserves-money multiplier relationship is not relevant to the determination of the money stock. Given the monetary rule, the actual evolution of money depends upon the real and monetary shocks (the $v_{t}$ and $n_{t}$ ) that impinge upon the system. In the 1950s, the Fed operated by controlling a rate of interest, rather than a reserve aggregate. Despite this fact, quantity theorists revived Pigou's reserves-money multiplier model, rather than Thornton's model. Thornton's model had disappeared in the Depression. The prevalence of "elasticity pessimism," the belief that economic agents are insensitive to relative prices in general and interest rates in particular, precluded its consideration. Even quantity theorists considered the 
central bank discount rate ineffective as an instrument of monetary control [Mints (1945), p. 279]. Perhaps quantity theorists espoused reserves-money multiplier models in the 1950 s because of a continuing belief that central bank manipulation of the interest rate was an ineffectual means of monetary control. Their concentration on reserves-money multiplier models, therefore, represented a normative choice about desirable monetary control procedures.

Probably more important was the unsatisfactory state of interest rate theory in the 1950s. Debate centered on loanable-funds versus liquidity-preference models, that is, over whether the interest rate is determined by excess demand in the market for credit or the market for the quantity of money. The development of general equilibrium analysis led to the abandonment of this debate as pointless. Discussion of the interest rate as a real phenomenon [for example Patinkin (1956), p. 267] was the exception. It was not until the natural rate-rational expectations models of the 1970 s that the natural-rate characteristic of the real rate of interest could be modeled in an analytically satisfactory way [Sargent (1973)]. Quantity theorists desired a theory of the money stock that allowed money to be exogenous in the context of the equation of exchange. It was, however, the natural rate concept that Thornton had exploited in order to achieve this exogeneity. In the general absence of this concept in the 1950s, quantity theorists did not appreciate the significance of his model.

Models of money with reserves-money multiplier relationships generally assume nonborrowed reserves control. Misunderstanding about the role assigned to nonborrowed reserves targets by the monetary authority has encouraged the inappropriate use of these models. It has not always been appreciated that nonborrowed reserves have often been manipulated by the monetary authority in order to control an interest rate operating variable. - / For example, in the 1950 s and 1960s and again recently, nonborrowed reserves have been manipulated only in order to maintain a positive level of borrowed reserves, that is, to 
"keep banks in the window." The level of the discount rate, taken in conjunction with a positive relationship between borrowed reserves and the marginal nonpecuniary costs of borrowing, is used to control the interest rate.

Multiplier formulas based on nonborrowed reserves targeting involve the ratio of borrowed reserves to deposits. If the central bank grants banks ready access to the discount window as a way of controlling the interest rate, this ratio will be interest elastic. The relevant model then is one where the monetary authority's instrument is an interest rate, rather than a reserve aggregate. If access to the window is tightly rationed or the discount rate is kept at a level that permits only frictional borrowing, the borrowed reserves to deposits ratio will be interest insensitive. The reserves-money multiplier relationship is then relevant.

In general, if any of the reserves to deposits ratios in money multiplier formulas are interest sensitive, these formulas do not constitute an anaiytically useful sumary of the key determinants of money. Their ratios then merely register the effects of more fundamental determinants of the money stock, like the shocks $v_{t}$ and $n_{t}$. This point can be made by considering the control of bank deposits by total reserves control. (It is assumed that only checkable deposits are reservable and that they are reservable at a uniform required reserve ratio.) The money stock remains subject to the same influences as with rate control, but now these influences must work through changes in bank excess reserves. For example, real and monetary shocks shift the bank credit demand schedule. Given the association of nominal credit and deposit creation, shifts in this schedule cause shifts in the reserve demand schedule. The money stock can change only if these shifts in reserve demand cause the excess reserves of banks change. If it is assumed that bank demand for excess reserves is interest insensitive, total reserves control can ensure efficient money stock targeting. 


\section{ii. Problems with empirical work}

In the post-War period, the use of reserves-money multiplier relationships to organize empirical work on the supply of money has often produced irrelevant results. Parameters from reserves-money multiplier formulas estimated with post-War data do not provide the intended empirical description of the supply of money. For example, in multiplier models, the elasticity of supply of total reserves and deposits depends upon the interest elasticity of free reserves. The assumption that the elasticity of free reserves (or its chief component, borrowed reserves) is a key empirical parameter of money stock determination has prompted a number of empirical studies [Polakoff (1960); Goldfeld and Kane (1966)]. In a regime of rate control, however, this elasticity is not a determinant of the money stock. $9 /$

Also problematic is the practice of using post-War data to estimate reserves-money multipliers in order to determine how closely the money stock could be controlled with a reserve-aggregate targeting procedure. [See Johannes and Rasche (1981).] For example, the behavior of reserves-money multipliers estimated with post-War data depends upon the behavior of excess reserves. This behavior would change with reserves control. Because the the Fed has operated with an interest rate instrument, the supply of reserves has accommodated whatever level of deposits and reserve demand has emerged at the targeted rate. With reserve-aggregate control where, in contrast, deposits are forced to adjust to reserves, excess reserves would become more variable. At the current low level of required reserve ratios, small exogenous changes in reserves would necessitate large changes in bank asset holdings. Reserve-aggregate control would increase the use by banks of their excess reserves as a temporary buffer between changes in reserves and assets. 
The Tinbergen model, as part of large-scale econometric models, has been estimated over periods like the 1950s and 1960s in which nonborrowed reserves control was only incidental to interest rate control. Such estimation will of course reveal a correlation between borrowed reserves and the interest rate, given the value of the discount rate. This correlation, however, does not describe a behavioral relationship significant in the determination of the money stock. Simulation of the estimated model under the assumption of nonborrowed reserve control is then subject to the Lucas critique.

In general, the Lucas critique is applicable to empirical work on bank behavior conducted without considering the way in which the monetary regime affects bank behavior. This point is made by Goodfriend (1983) in his criticism of existing regression analysis explaining borrowed reserves. He points out that banks are rationed in their use of the window through a limitation on the allowable quantity of borrowing over a period of time. Banks try to distribute their borrowing so that it occurs when the differential between the funds rate and discount rate is relatively high. Banks, then, are required to forecast the future level of interest rates. With rational expectations, this requirement makes bank borrowing behavior depend upon the character of the monetary regime.

\section{iif. The reverse-causation debate}

Interest rate smoothing by the monetary authority makes reserves and the money stock endogenous. Especially in the 1960s, it was argued that this endogeneity renders the quantity theory problematic. Davis (1968, p. 68) used reserve endogeneity to criticize Friedman's explanation of the business cycle. Tobin (1963, p. 230) argued that it allows banks to adjust their nominal deposIts in response to changes in the public's demand for real deposits.

In arguing the exogeneity of money in the context of the equation of exchange, quantity theorists emphasized the stability of reserves-money multiplier relationships. They then argued that because the monetary authority 
creates reserves the money stock is, at least in part, caused by the monetary authority, rather than the public. [See also Warburton (1975).] $\underline{10 /}$

(1) Federal Reserve actions dominate the movement of the monetary base over time; (ii) movements of the monetary base dominate movements of the money supply over the business cycle; and, (iii) accelerations or decelerations of the money supply are closely followed by accelerations or decelerations in economic activity. Therefore, the Monetarist thesis puts forth the proposition that actions of the Federal Reserve are transmitted to economic activity via the resulting movements in the monetary base and money supply [Brunner (1968), p. 24].

This rebuttal of the "reverse-causation" criticism was ill founded given the irrelevance of the reserves-money multiplier relationship in the contemporaneous monetary regime of rate control. In the context of the natural-rate model of Sec. 2, quantity theorists should have responded that the endogeneity of reserves and the money stock possesses no implications for the usefulness of organizing an analysis of the price level and nominal income around the behavior of the money stock. The analytical usefulness of the quantity theory depends upon the extent to which independent movements occur in the nominal money supply and demand schedules. The importance of independent movements increases as the magnitude of real shocks rises relative to monetary shocks and as the monetary authority attempts to control real variables.

\section{Models of bank behavior}

1. Choice of model

Economists' choice of analytical apparatus to study bank behavior, like their choice of a model of money, depends on the role assigned to the price level. This point is made below with an example of analysis from the quantity theory tradition and a contrasting example from the real bills or banking school tradition. In A Tract on Monetary Reform and A Treatise on Money, Keynes argued that the central bank should control the money stock in order to achieve price level stability. Control of the money stock was to be effected within the framework of a reserves-money multiplier and reserves targets. Keynes desired 
an analytical apparatus with banks as "creators" of nominal money, albeit constrained by the reserve creation of the central bank. He wanted a model that distinguished between bank creation of nominal deposits and bank intermediation of real savings in the form of real deposits [Keynes (1930), vol. 6, p. 191]:

A banker. . . is acting both as provider of money for his depositors, and also as a provider of resources for his borrowing customers. Thus the modern banker performs two distinct sets of services. He supplies a substitute for State [high-powered] Money by acting as a clearing-house and transferring current payments. . . But he is also acting as a middleman in respect of a particular type of lending, receiving deposits from the public which he employs in purchasing securities, or in making loans... . This duality of function is the clue to many difficulties in the modern Theory of Money and Credit and the source of some serious confusions of thought.

According to Keynes, analysis of the role of banks as intermediaries between savers and investors can be conducted soley in real terms. Analysis of their role as suppliers of money must distinguish between real and nominal money. If It does not, it ignores the fact that "the manufacture of Representative Money [bank deposits] uses up no real resources" [Keynes (1930), vol. 6, p. 214 ] Tobin (1963), implicitly arguing from the Tinbergen model, contends that introducing the public's money demand function into a theory of the money stock invalidates the logic of the quantity theory, which requires that the price level vary in order to cause nominal money to yleld the amount of real purchasIng power demanded by the public. The public procures the real purchasing power of money it demands, Tobin asserts, through direct adjustment of the quantity of (nominal) money. In the spirit of the Tinbergen model, no distinction is made between real and nominal deposits or between financial intermediation and the determination of bank deposits. Banks are solely intermediaries between savers and investors, not creators of money [Tobin (1963), p. 227]:

- . a bank can make a loan by "writing up" its deposit liabilities... . Borrowers do not incur debt in order to hold idle deposits. . . . The borrower pays out the money.. . . Whether or not it stays in the banking system . . . depends on whether somewhere in the chain of transactions initiated by the borrower's outlays are found depositors who wish to hold new deposits. 
ii. Irrelevance of the deposit expansion and contraction process Since Phillips (1921), reserves-money multiplier formulas have been derived from a model of the banking sector summarized in the multiple expansion of deposits produced by an injection of reserves. $\frac{11 /}{}$ The existence of markets for bank reserves, however, renders this model untenable. Phillips' model assumes that the individual bank is constrained by the quantity of its reserves and that its asset acquistion and deposit creation are driven by discrepancies between actual and desired reserves. Given the existence of markets for bank reserves, such as the fed funds and $C D$ markets, however, individual banks are constrained by the price, rather than the quantity, of reserves they hold. An alternative to Phillps' model of individual bank behavior is offered below.

Banks are middlemen between Investors and savers. The market for bank credit summarizes the return to lending to investors. The market for reserves summarizes the cost of borrowing from savers. $\frac{12 /}{}$ The price of reserves constrains the asset acquisition of banks. A bank purchases an asset by crediting, either directly or via a correspondent bank, the deposit account of the seller of the asset. The cost of purchasing an asset depends upon the price of the reserves that must be replaced when the seller draws down his account. When interest rates in the credit and reserves markets differ, banks have an incentive to alter their holdings of interest-bearing assets. Changes in bank credit and deposits derive from bank arbitrage of the rates in these two markets.

Fig. 1 depicts the markets for bank credit and reserves. It is assumed that the monetary authority targets total reserves and that the resulting vertical reserve supply schedule, $R^{s}$, fluctuates randomly around a fixed level, $R_{0}{ }^{\cdot}$ The reserve demand schedule, $\mathrm{R}^{\mathrm{d}}$, is drawn for a given level of deposits. Its downward slope reflects negative interest elasticity of demand for excess reserves. The intersection of the reserve supply and demand schedules determines the funds rate, rf. The bank credit demand schedule, $B C^{d}$, is drawn for 


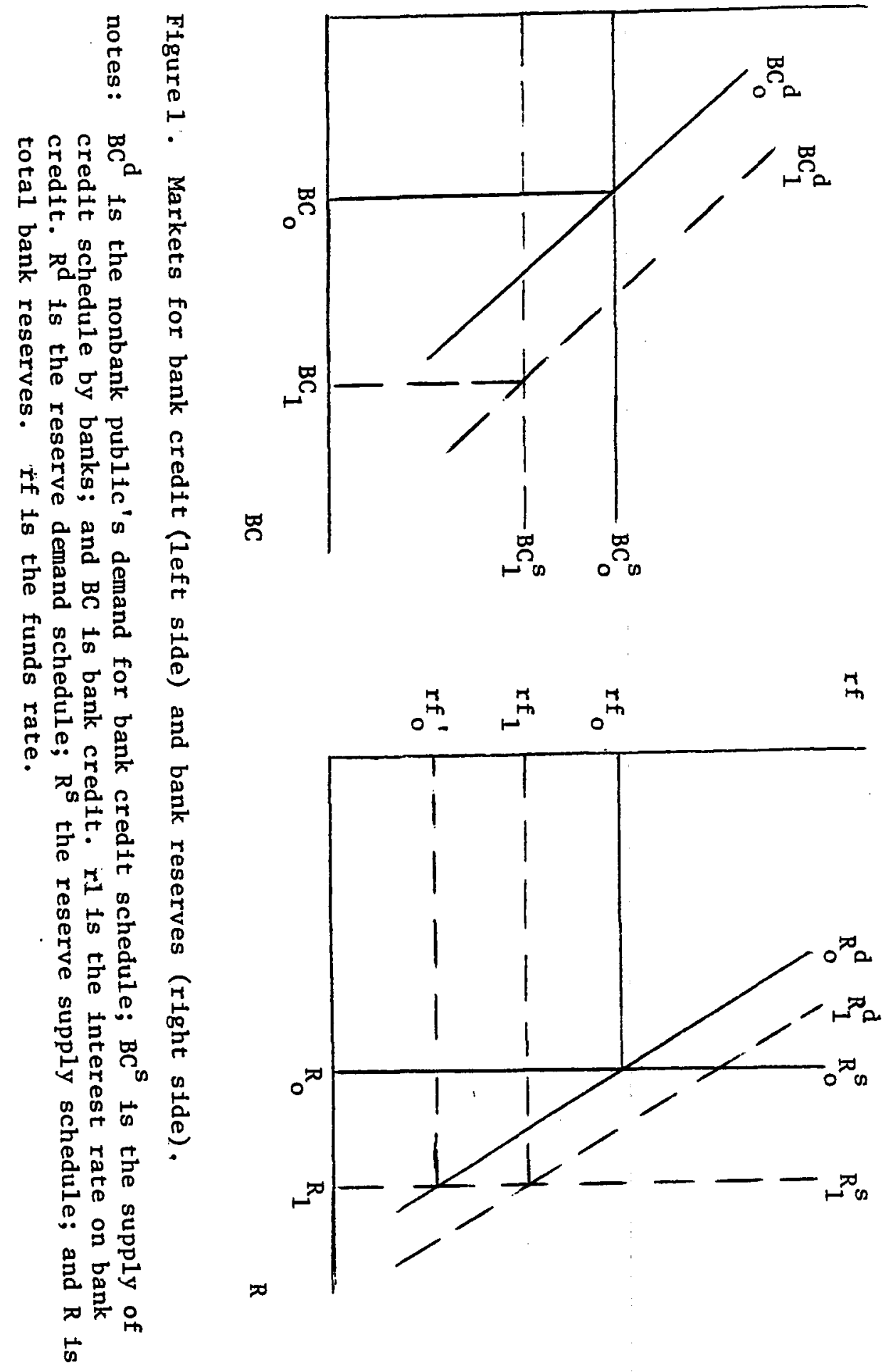


the price level consistent with the level of deposits assumed for the reserve. demand schedule. At the existing funds rate, which is taken as given by individual banks, banks will supply whatever credit their customers demand. For this reason, the supply of bank credit schedule, $\mathrm{BC}^{\mathrm{s}}$, is horizontal. $13 /$

Consider now a positive shock to reserves, shown by $R_{1}$. The funds rate falls from $r f_{0}$ to $\mathrm{rf}_{0}^{\prime}$. (At the original funds rate, banks' ratio of reserves to deposits now exceeds the equilibrium ratio. As they attempt collectively to sell reserves, the funds rate falls.) With the price of acquiring assets (the price of replenishing reserves), $r f$, less than the return to acquiring assets, $r 1_{0}$, banks acquire assets. As a consequence of asset acquisition, their deposits increase. This increase in deposits lowers the reserves/deposits ratio of banks and causes their reserve demand schedule to shift rightward to $R_{1}^{d}$. As described in Sec. 2, the increase in deposits $\left(m_{t}\right)$ stimulates real output and raises prices. The rise in prices causes the bank credit demand schedule to shift rightward to $\mathrm{BC}_{1}^{d}$. (In final equilibrium, the price level rises by the same proportion as reserves, and interest rates return to their original levels.) With total reserves control, the deposits of the banking system adjust to the reserves of the banking system, and the reserves-money multiplier relationship is a useful summary of the determinants of the money stock. Phillips' model, however, lacks relevance.

\section{Hodels of the money stock and policy}

It has been argued that the role economists assign to the price level determines their choice of model of the money stock. It is instructive to apply this generalization to the choice by the Fed of the model of the money stock used in its policy deliberations. Monetary policy evolves under the assumption that an optimal long-run policy will result from a concatenation of policy actions, each of which appears optimal within the context of a short time horizon. No systematic procedure is imposed whereby long-run objectives con- 
strain policy actions. Each period the policy maker retains the freedom to alter the relative priorities assigned to ultimate objectives [Hetzel (1986)]. Within this decision-making framework, it is natural for the monetary policymaker to take the price level as given over the immediate policy horizon [Barro and Gordon (1983)].$\underline{14 /}$

The Tinbergen model concentrates analysis at a point in time, rather than on the evolution of stock equilibrium over time. In a point in time exercise, it is natural to take the price level as given. The Tinbergen model then was the natural model for the Fed to use in its policy deliberations. $\frac{15 /}{}$ With the price level taken as given, there is no need to distinguish between nominal and real magnitudes. The implicit assumption that the price level is given produces a one-to-one association between the interest rate and nominal (real) money. In this way, the Tinbergen model appeared to capture the dilemma of policy as perceived by the Fed in the 1970s. It could avoid overshooting its target for money, but only if it were willing to accept a higher rate of interest.

In the Tinbergen model, the monetary authority induces changes in money by engineering changes in market rates that move the public along its money demand schedule. The low interest elasticity estimated for real money demand appeared in the 1970 s to require unacceptably large increases in rates in order to rectify overshoots of the Ml target. Also, the initial coefficients estimated on the contemporaneous and lagged interest rate term in the Board's monthly money market model were small relative to later terms. It was argued that with this pattern of coefficients attempts to target money closely would produce large cycles in money and interest rates [Ciccolo (1974)]. These implications of the Tinbergen model increased Fed reluctance to achieve its Mi target.

\section{Concluding comment}

According to the real bills and banking school, the demand for real money determines the quantity of nominal money. According to the quantity theory, at 
least some of the determinants of the supply of nominal money differ from the determinants of the demand for real money. With the real rate of interest and real output determined ultimately as nonmonetary phenomena, the price level must vary in order to make the quantity of real money equal to the quantity of real money desired by the public. These schools assign different roles to the price level. Economists choose models of the money stock according to the roles they assign to the price level. The common fallure to include the determination of the price level explicitly in models of the money stock, however, has made the character of the resulting models ambiguous. In particular, one cannot determine to what extent, if any, the determinants of real money differ from the determinants of nominal money. Also, economists have commonly failed to incorporate the way in which the monetary regime affects the behavioral relations relevant to determination of the money stock. Consequently, there is a great deal of confusion about which models of money are relevant to which monetary regimes. 


\section{Pootnotes}

1. Goodfriend (1986) studies the stochastic behavior of nominal money and the price level in the general case where the extent to which innovations in money are offset can 11 e anywhere between the extremes represented by (4) and (5). 2. The two kinds of interest rate targets mentioned here, an interest rate target used as an instrument for controlling a nominal (intermediate or ultimate) objective and a straight interest rate peg, imply very different monetary regimes. When it is not necessary to distinguish the two kinds of regimes, reference is simply made to a "regime of rate control."

3. First, use (3) and (4) to eliminate $h_{t}$, the reserve aggregate, and to produce an expression for $m_{t}$. This expression yields an expectation of $m_{t+1}$. Note that $E\left(r_{t+1}: I_{t-1}\right)=\bar{r}$, given that $u_{1}$ in (3) and $\bar{r}$ are chosen to be compatible. Therefore, the term $E\left(r_{t+1}-\bar{r}\right)$ is zero. Now let $\lambda$ become arbitrarily large in order to peg $r_{t}$ at $\bar{r}$. The result is

$$
E\left(m_{t+1}: I_{t-1}, \bar{r}\right)=\left(d_{0}+d_{2} u_{0}\right)+d_{1} \bar{r}+\left(d_{2} u_{1}\right) t .
$$

Equation (6) and its counterparts specify a future path for expected money. Equations (1) and (2) and this path allow formation of an expectation of $p_{t+1}$. 4. This accommodation could be seen in the 1970 s when the Fed targeted the funds rate. Because of lagged reserve accounting, changes in reserves followed changes in deposits with a two week lag.

5. Non-interest-bearing reserves constitute the base of a tax on bank intermediation. The reserves-deposits ratio of banks then has implications for the demand for real money through its effect on the cost of intermediation.

6. The assumed nonmonetary character of the determinants of the scale variable in the money demand function is reflected in the comment that this variable "Is 1ikely in general to be increased by developments that bring the forces of nature more effectively under man's control; such as an increase in the efficlency of the people.. through mechanical inventions or through inventions 
In business organization" [Pigou.(1917), p. 166]. Pigou [1917, pp. 168-9] assumes that the demand for money depends upon the alternative real resource cost of holding money [for example, "the expected fruitfulness of industrial activity"] and the inflation rate. These factors are captured by the nominal interest rate. Pigou, however, does not include the interest rate explicitly in his model, so the price level is left as the sole equilibrating variable. 7. Through a series of papers written in the 1960 s and early 1970s, Karl Brunner and Allan Meltzer became the most persistent advocates of expositing theorles of the money stock in a general equilibrium framework. A summary of their model is contained in Brunner (1973). They incorporate a reserves-money multiplier relationship into a model in the spirit of the neoclassical synthesis of Keynesian macroeconomics that occurred in the 1960s. Explicit incorporation [Brunner and Meltzer (1972)] of a market for real capital facilitated their criticism of models of money making excess demand in the market for the quantity of money Identical to excess supply in the credit market, for example, Gramley and Chase (1965). The quantity theory character of their model of the money stock derives from its incorporation of a long-run vertical Phillips' curve [Brunner and Meltzer (1976), p. 84].

8. An example of this misunderstanding occurred when the Fed announced a change in operating procedures on October 6, 1979 [Hetze1 (1982)]. The operating variable of immediate concern to the Desk was changed from the funds rate to nonborrowed reserves. Many economists concluded incorrectly that the new procedures represented monetary control within a reserves-money multiplier framework. With lagged reserve accounting, however, bank demand for total reserves was essentially predetermined. The new procedures worked by supplying an amount of nonborrowed reserves less than the predetermined demand for total reserves and, thus, by forcing banks into the discount window. The cost of borrowing at the window then determined the funds rate. That is, the funds rate 
equalled the discount rate plus an amount varying positively with borrowed reserves. The funds rate determined the cost of bank credit extension and, in combination with the demand for bank credit schedule, determined bank asset acquisition and, as a consequence, bank liabilities and the money stock. In sum, the new procedures, like the old, worked through control of the funds rate, although this control was exercised indirectly under the new procedures.

9. Given the discount rate, a decreased sensitivity of borrowed reserves to the interest rate increases the level of nonborrowed reserves required in order to achieve a rate target. The interest sensitivity of free reserves, therefore, affects the division of total reserves between nonborrowed and borrowed reserves. Given the rate target, however, this division does not affect the magnitude of the money stock. (This division has implications for how the monetary authority shares the seigniorage from reserve creation with banks.) 10. The major response of quantity theorists to the "reverse causation" criticism was that the persistence of empirical regularities between money and nominal output over different kinds of monetary regimes implies that the primary influence runs from money to nominal output, rather than vice versa [Brunner (1971), p. 99; Friedman and Schwartz (1982), p. 626].

11. There were good reasons in the 1920 s for the popularity of Phillips' model. Under the influence of Reynes, economists at Cambridge in particular began to advocate control of bank deposits and credit in order to stabilize the price level. These ideas were resisted by bankers, who criticized the idea that banks create deposits and argued instead that banks only relend deposits entrusted to them by the public. They argued that banks cannot create deposits because of the discipline exerted on deposit creation by reserve drains. Phillips' exposition of the multiple expansion process was a tailor-made refutation to bankers' denial that banks can create money. 
12. Banks acquire reserves in many markets, 11ke the Eurodollar, RP, and CD market. Because they arbitrage rates across these markets, the funds rate can then be used as a proxy for the price of obtaining reserves. 13. Because nominal credit creation by banks does not require real resources, it is not constrained by the real marginal cost curve applicable in the theory of the firm. The model then is in the spirit of models advocated in the quotatIon from Keynes in the preceding subsection. The contrary view is reprsented by Tobin. [See Pesek (1976) for an extended statement of Tobin's view.] Intermediation of the public's real savings does involve real costs. These costs are captured by the markup of the loan rate over the funds rate (abstractIng from term-structure complications). This differential can affect the nominal quantity of bank credit transitorily, for example, by affecting the extent to which intermediation occurs through banks as opposed to the commercial paper market [Hetzel (1982), Sec. 5].

14. Alternatively, the policymaker could start with a long-term objective, for example, price level stability. Optimal policy in the long run could then be viewed as being achleved through the constraint that the long-term objective places on policy actions each period. The actual polfcy procedure, which allows the contemporaneous inflation rate to be considered as given, facilitates near-term forecasting of the economy. The alternative procedure would elucidate more clearly the way in which past actions constrain the policymaker's current cholces. The concern of policy with the near-term behavior of the economy dictates the actual procedure.

15. Hetzel (1981) and Lombra and Moran (1980) describe the use of the Board's money market model (the Tinbergen model) in the preparation of the Bluebook, a document used by the Federal Open Market Committee. Since the ear1y 1970s, this model has been used by the Board staff to offer the FOMC a menu of paired cholces of inversely-related values of the funds rate and rates of money growth. 


\section{BIBLIOGRAPHY}

Barro, Robert J. and Gordon, David B. "A Positive Theory of Monetary Policy in a Natural Rate Mode1," Journal of Political Economy, Aug. 1983, 91(4), pp. 589-610.

Brunner, Karl. "The Role of Money and Monetary Policy," Federal Reserve Bank of St. Louis Review, July 1968, 50(7), pp. 9-24.

- "A Survey of Selected Issues in Monetary Theory," Schweizerische Zeitschrift fur Volkwirtschaft und Statist1k, March 1971, 107(1), pp. 1-146.

- "A Diagrammatic Exposition of the Money Supply Process," Schweizerische Zeitschrift fur Volkswirtschaft und Statistik, Dec. 1973, 109(4), PP. 481-533.

Brunner, Rarl and Meltzer, Allan H. "Money, Debt, and Economic Activity," Journal of Political Economy, Oct. 1972, 80(5), Pp. 951-77.

- "An Aggregative Theory for a Closed Economy," In Monetarism. Ed.: Jerome L. Stein. Amsterdam: North Holland, 1976, 69-103.

Canzoner1, Matthew B.; Henderson, Dale W. and Rogoff, Kenneth S. "The Information Content of the Interest Rate and Optimal Monetary Policy," The Quarterly Journal of Economics, Nov. 1983, 98(4), pp. 545-65.

Ciccolo, John H. "Is Short-run Monetary Control Feasible," in Monetary Aggregates and Monetary Policy. Federal Reserve Bank of New York, Oct. 1974, pp. 82-91.

Davis, Richard G. "The Role of the Money Supply in Business Cycles," Federal Reserve Bank of New York Monthly Review, Apr11 1968, 50(4), pp.63-73.

- "ImplementIng Open Market Policy with Monetary Aggregate Objectives," in Monetary Aggregates and Monetary Policy. Federal Reserve Bank of New York, 1974, PP. 7-19.

de Leeuw, Frank. "A Model of Financial Behavior," In The Brookings Quarterly Econometric Model of the United States. Ed.: J. Duesenberry, et al. Chicago: Rand McNally and $\mathrm{Co} ., \overline{19} 65, \mathrm{PP} .465-530$.

Dotsey, Michael and King, Robert G. "Monetary Instruments and Policy Rules in a Rational Expectations Environment," Journal of Monetary Economics, Sept. 1983, 12(3), pp. 357-82.

Friedman, Milton and Schwartz, Anna. Monetary Trends in the United States and the United Ringdom. Chicago: The University of Chicago Press, $\frac{1982 .}{19}$

Goldfeld, Stephen M. Commercial Bank Behavior and Economic Activity. Amsterdam: North Holland, 1966.

Goldfeld, Stephen M. and Rane, Edward J. "The Determinants of Member Bank BorrowIng: An Econometric Study," Journal of Finance, Sept. 1966, 21 (3), pp. 499-514.

Goodfriend, Marvin. "A Model of Money Stock Determination with Loan Demand and a Banking System Balance Sheet Constraint," Federal Reserve Bank of Richmond Economic Review, Jan./Feb. 1982, 68(1), pp. 3-16. 
. "Discount Window Borrowing, Monetary Policy, and the Post-October 6, 1979 Federal Reserve Operating Procedures," Journal of Monetary Economics, Sept. $1983,12(3)$, pp. 343-56.

. "Interest Rate Smoothing and Price Level Trend Stationarity." Federal Reserve Bank of Richmond Working Paper, April 1968.

Gramley, Lyle and Chase, Samuel B. "Time Deposits in Monetary Analysis," Federal Reserve Bulletin, Oct. 1965, 51(10), pp. 1380-1406.

Hetzel, Robert L. "The Federal Reserve System and Control of the Money Supply in the 1970s," Journal of Money, Cred1t, and Bank1ng, Feb. 1981, 13(1), pp. 31-43.

- "The October 1979 Regime of Monetary Control and the Behavior of the Money Supply in 1980," Journal of Money, Credit and Banking, May 1982, 14(2), pp. 234-251.

"A Congressional Mandate for Monetary Policy," The Cato Journal, Winter 1986, 5(3), Pp. 797-820.

- "Money Stock Determination in a Monetary Regime of Rate Targeting: A HistorIcal Survey." Federal Reserve Bank of RIchmond Working Paper, June 1986.

Johannes, James M. and Rasche, Robert H. "Can the Reserves approach to Monetary Control Really Work?" Journal of Money, Credit, and Banking, Aug. 1981, 13(3), pp. 298-313.

Kaminow, Ira. "Required Reserve Ratios, Policy Instruments, and Money Stock Contro1," Journal of Monetary Economics, Oct. 1977, 3(4), pp. 389-408.

Keynes, John Maynard. A Tract on Monetary Reform (1923). in The Collected Writings of John Maynard Keynes, vol. 4. London: The Macmillan Press, 1971.

- A Treatise on Money (1930). In The Collected Writings of John Maynard Reynes, vol. 5 and 6. London: The Macmillan Press, 1971.

- The General Theory of Employment, Interest and Money (19.36). In The Collected Writings of John Maynard Keynes, vol. 7. London: The Macmillan Press, 1973.

Lombra, Raymond E. and Moran, Michael. "Pollcy Advice and Policymaking at the Federal Reserve," Carnegle-Rochester Conference Serles on Public Policy, 1980, 13, pp. 9-68.

LeRoy, Stephen F. "Monetary Control under Lagged Reserve Accounting," Southern Journal of Economics, Oct. 1979, 46(2), pp. 460-70.

Lindsey, David E.; Farr, Helen T.; Gillum, Gary P.; Kopecky, Kenneth J. and Porter, Richard D. "Short-run Monetary Control, Evidence Under a Nonborrowed Reserve Operating Procedure," Journal of Monetary Economics, Jan. 1984, 13(1), pp. 87-111.

McCallum, Bennett T. "Price Level Determinacy with an Interest Rate Policy Rule and Rational Expectations," Journal of Monetary Economics, Nov. 1981, 8(3), pp. 319-29. 
- "Some Issues Concerning Interest Rate Pegging, Price Level Determinacy, and the Real Bills Doctrine," Journal of Monetary Economics, Jan. 1986, 17(1), 135-160.

Mints, Lloyd W. A History of Banking Theory. Chicago: University of Chicago Press, 1945.

Modigliant, Franco; Rasche, Robert and Cooper, J. Philip. "Central Bank Policy, the Money Supply, and the Short-Term Rate of Interest," Journal of Money, Credit and Banking, May 1970, 2(2), pp. 166-218.

Parkin, Michael. "A Comparison of Alternative Techniques of Monetary Control Under Rational Expectations," Manchester School, Sept. 1978, 46(3), pp. 252-87.

Patinkin, Don. Money, Interest and Prices. NY: Row, Peterson, and Co., 1956.

- "Financial Intermediaries and the Logical Structure of Monetary Theory," The American Economic Review, March 1961, 51(1), 95-116.

Pesek, Boris P. "Monetary Theory in the Post-Robertson 'Alice in Wonderland' Era," Journal of Economic Literature, Sept. 1976, 14(3), pp.856-884.

Phillips, Chester A. Bank Credit. NY: The Macmillan Co., 1921.

Plerce, James L. and Thomson, Thomas D. "Some Issues in Controlling the Stock of Money," In Controlling Monetary Aggregates II: The Implementation. Federal. Reserve Bank of Boston, Sept. 1972, Pp. 115-36.

Pigou, Arthur C. "The Value of Money," Quarterly Journal of Economics, Nov. 1917, 32, pp. 38-65.

Polakoff, Murray E. "Reluctance Elasticity, Least Cost, and Member Bank Borrowing: A suggested Integration," Journal of Finance, March 1960, 15(1), pp. 1-18.

Sargent, Thomas J. "Rational Expectations, the Real Rate of Interest, and the Natural Rate of Unemployment," Brookings Papers on Economic Activity, 1973, 2," pp. 429-72.

- Macroeconomic Theory. NY: Academic Press, 1979.

Sargent, Thomas J. and Wallace, Ne1l. "'Rational' Expectations, the Optimal Monetary Instrument, and the Optimal Money Supply Rule," Journal of Political Economy, Apr11 1975, 83(2), pp. 241-54.

Sivesind, Charles and Hurley, Kevin. "Choosing an Operating Target for Monetary Policy," Quarterly Journal of Economics, Feb. 1980, 94(1), pp. 199-203.

Telgen, Ronald L. "The Demand for and Supply of Money." In Readings in Money, National Income and Stablilzation Policy. Eds.: W. L. Smith and $\bar{R}$. $\overline{\text { L. Telgen. }}$ Homewood, I11.: R1chard D. IrwIn, 1970, pp. 74-112.

- "Demand and Supply Functions for Money in the Unfted States: Some Structural Estimates," Econometr1ca, Oct. 1964, 32(4), pp.476-509.

Thomson, Thomas D.; Plerce, James L, and Parry, Robert T. "A Monthly Money Market Mode1," Journal of Money, Credit and Banking, Nov. 1975, 7(4), 411-31. 
Thornton, Henry. An Enquiry into the Nature and Effects of the Paper Credit of Great Britain (1802) and Two Speeches (1811), edited with an Introduction by $F$. A. v. Hayek. NY: Rinehart and Co., 1939.

Tinbergen, Jan. Statistical Testing of Business Cycle Theories. Geneva: League of Nations, 1939. - Econometrics. NY: The Blakiston Co., 1951.

Tinsley, Peter A.; Farr, Helen T.; Frles, Gerhard; Garrett, Bonnie and von zur Muehlen, Peter. "Policy Robustness: Specification and Simulation of a Monthly Money Market Model," Journal of Money, Cred1t, and Banking Nov. 1982, 14(4), Part 2, pp. 829-56.

Tobin, James. "Commercial Banks as Creators of 'Money'," in Banking and Monetary Studies. Ed.: Deane Carson. Homewood, I11.: Richard D. Irwin, 1963, Pp. 408-19.

Warburton, Clark. "Endogeneity of Federal Reserve Behavior and the System's Responsibility for the Stock of Money: Comment," Southern Economic Journal, Oct. 1975, 42(2), PP. 299-302. 